\title{
砂浜域の港湾構造物における 藻場の持続的な形成要因
}

\author{
佐藤 仁 1 ・山本 潤 1 山内弘明 2 ・今林 弘 2 ・山下俊彦 3 \\ 1正会員 (独法) 土木研究所寒地土木研究所 ( $\bar{T} 062-8602$ 札幌市豊平区平岸1条3丁目) \\ 90190@ceri.go.jp \\ 2国土交通省北海道開発局釧路開発建設部釧路港湾事務所（二084-0914 釧路市西港1丁目） \\ yamauchi-h22aa@hkd.mlit.go.jp \\ 3 正会員 北海道大学教授 大学院工学研究院 (060-8628 札幌市北区北13条西 8 丁目) \\ y-toshi@eng. hokudai.ac.jp
}

\begin{abstract}
砂浜域に位置する重要港湾釧路港の島防波堤では，浚渫土砂を利用した背後盛土により，浅場を利用し た岩礁性藻場の創出機能を付加させている. 本構造物の藻場機能については, 初期段階の検討は行われて いるが，長期的な藻場の形成過程や環境条件などについては不明な点が多い.

本研究は，長期間にわたる調査により，砂浜域に形成された岩礁性の藻場創出効果の持続要因について 検討した。 その結果, 砂浜域に創出された背後盛土は, 岩礁性の海藻群落が持続的に形成され, 十分に藻 場創出機能を有している．また，海藻着生は天端部に限られるが，濁りのある砂浜海域においても海藻の 生育に必要な光環境が良好であることが判明した。
\end{abstract}

Key Words : Kushiro Port, breakwater rear step, seaweed bed, generation change, light and turbidity

\section{1. はじめに}

北海道東部太平洋に位置する重要港湾釧路港の 島防波堤は，浚渫土砂を利用した水深の浅い背後盛 土構造を付加させている。この構造物は，防波堤に 求められる本来機能に加えて, 背後盛土上の浅場を 利用して藻場造成を図り，水生生物の生息環境の創 出をめざしている（図-1）。藻場は海洋生物の産卵 場，摂餌場あるいはそれ自体が基礎生産者としての 役割を持つなど，様々な機能が複合的に機能してお り，良好な海域環境を創造するための基盤となるも のである ${ }^{1)}$.

背後盛土上における藻場の形成については，北 原ら ${ }^{2)}$, 佐藤ら ${ }^{3)}$ がその初期段階における海藻繁茂 状況や生物生息状況等を検討している. それによる と, 背後盛土は整備から約 2 年半経過した段階にお いて藻場造成効果が認められ, 沿岸構造物の自然環 境調和機能が発現していることが判明している。し かしながら, その後の藻場の状況や生物生息場とし ての効果については検討されていない。一方，岩礁 性藻場の形成要因については，いわゆる磯焼けが顕 著に見られる日本海側における研究事例は多いもの の, 当海域のような砂浜海域に新たに創出された岩 礁性藻場の特徵については不明な点が多い. 特に藻 場造成効果を持続させるためには, 海藻の遷移や多

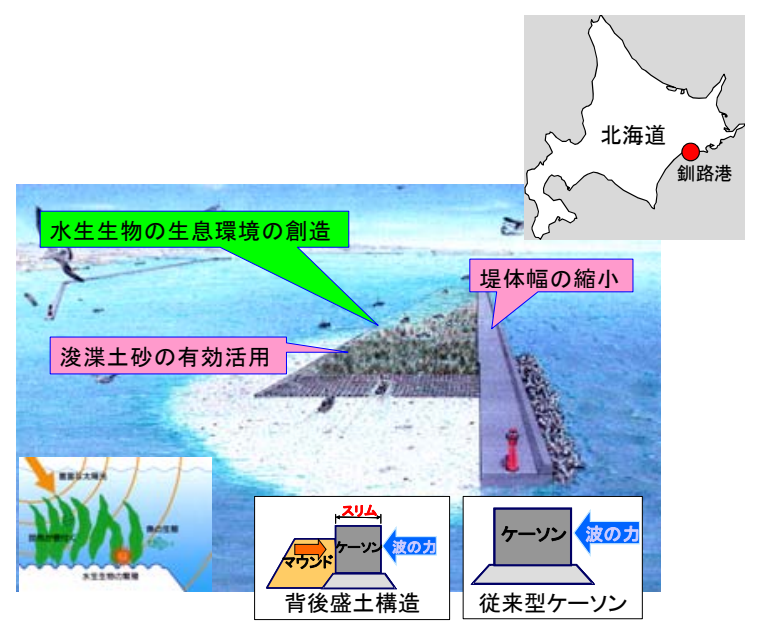

図-1 背後盛土付防波堤の特徵

年生海藻の生態サイクル, 新規加入群による世代交 代の有無が重要な要素となる.

本研究は, 初期段階におけるこれまでの検討結 果とあわせて，藻場の生態サイクルに沿った長期間 にわたる海藻着生効果の知見を加え, 砂浜域に形成 された岩礁性の藻場造成効果の持続要因について検 討したものである。 


\section{2. 藻場創出に関わる環境因子}

一般的に藻類の生育環境因子は物理的要因，化 学的要因, 動力学的要因, 生物的要因などに分類さ れる (表-1） ${ }^{3)}$ 。例えば，北海道日本海側の磯燒け を受ける岩礁地带では, 水温上昇, 栄養塩類, 藻食 動物（ウ二類）の食害などが因子となる。しかしな がら，砂浜域に形成される岩礁性藻場においては,

(1)光量子量

(2)浮泥堆積量

が重要な因子になると考えられる.このうち, 光量 子量は光合成に不可欠であり, 釧路周辺海域が高栄 養塩・低透視度を特徵とする親潮の影響を受けてい ることから最も重要な因子である。他方, 浮泥は一 定以上の厚さで海藻の付着基盤に堆積した場合, 海 藻胞子の着生阻害や着生した胞子も成長が阻害され る要因となる。つまり, 背後盛土上に造成された藻 場においては, その生長に十分な光量子量の到達深 度の確保と海藻着生阻害を引き起こす浮泥の払拭の 2 点が, 藻場を持続的に維持させる条件と考えられ る。

\section{3. 調査方法}

（1）釧路港島防波堤背後盛土について

対象とする釧路港島防波堤の標準断面図を図-2

表-1 藻類の生息環境因子

\begin{tabular}{|c|c|}
\hline 物理的要因 & $\begin{array}{l}\text { 光 (光量子量) } \\
\text { 付着基質 (浮泥の状況、安定性、表面形状等) } \\
\text { 温度 (海水温) } \\
\text { 淡水 (河川水、降雨等) }\end{array}$ \\
\hline 化学的要因 & $\begin{array}{l}\text { 塩分 } \\
\text { 栄養塩類(窒素、リン等必須代謝物質) } \\
\text { 光合成を行うための遊離二酸化炭素 } \\
\mathrm{pH} \\
\text { 污染 (有機質、無機質、生物質) }\end{array}$ \\
\hline 動力学的要因 & $\begin{array}{l}\text { 海水の流動(海流、波浪、潮汐、湧昇流） } \\
\text { 潮汐による干出 } \\
\text { 風 }\end{array}$ \\
\hline 生物的要因 & $\begin{array}{l}\text { 藻食動物による食害 } \\
\text { 基質への競合 } \\
\text { 繁茂による光の制限 }\end{array}$ \\
\hline
\end{tabular}

に示す. 背後盛土は越波した波を減衰させる打込対 策部 $40 \mathrm{~m}$, 海藻を繁茂させる藻場部 $60 \mathrm{~m}$ に大別され る. 藻場部の構造は水深 $-15 \mathrm{~m}$ 程度の砂地盤から水 深-5m まで浚渫土砂で高上げし，雑割石，大割石で 被覆（水深-3m）を行い，その上に起伏工（水深-1m） を設置している。本断面構造は，1998 年～2007 年 に開催された「釧路港島防波堤施設検討委員会」で 検討されたものである。本検討では，「構造面」・

「施工面」・「環境面」から様々な検討が成されて いる.

なお，島防波堤は，1998 年 6 月に旧運輸省から 藻場機能を持つ「水生生物との協調型防波堤」とし て，直轄事業では初めてエコポートモデル事業に認 定された. 2011 年 3 月現在, 図-3 に示すとおり島 防波堤本体工は全体計画延長 2,500m のうち $1,660 \mathrm{~m}$ が完成し，背後盛土部分は $1,600 \mathrm{~m}$ のうち実証試験 区間として $100 \mathrm{~m}$ が完成している（2005 年 12 月完 成）.

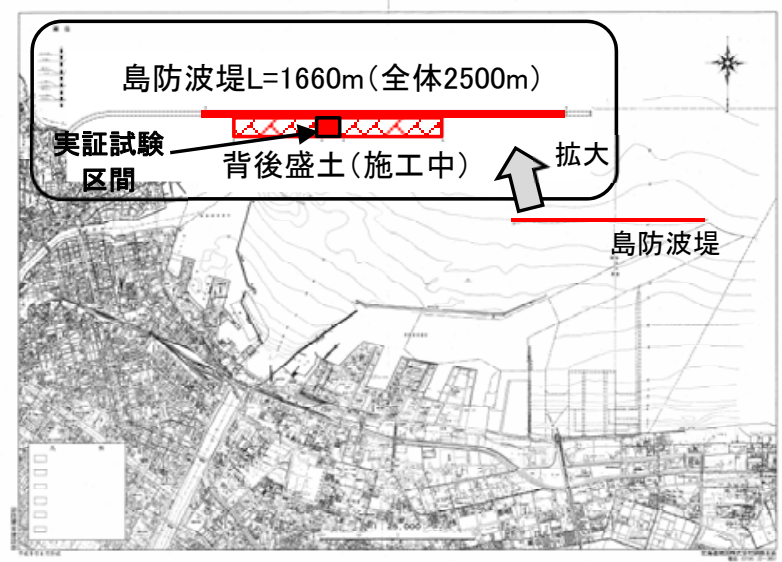

図-3 釧路港島防波堤平面図

\section{(2) 背後盛土の藻場環境に関する調査}

藻場の把握は，実証試験区間が完成した直後の 2006 年からのモニタリング調査で行っている. 背 後盛土上における調查箇所を図-4に示す。調査は 毎年, 海藻が最も繁茂している夏期, 年間を通じて 最も波高が高い秋期，海藻が生長する春期の 3 期に 実施している。海藻繁茂調査は，A 区画〜 E 区画の

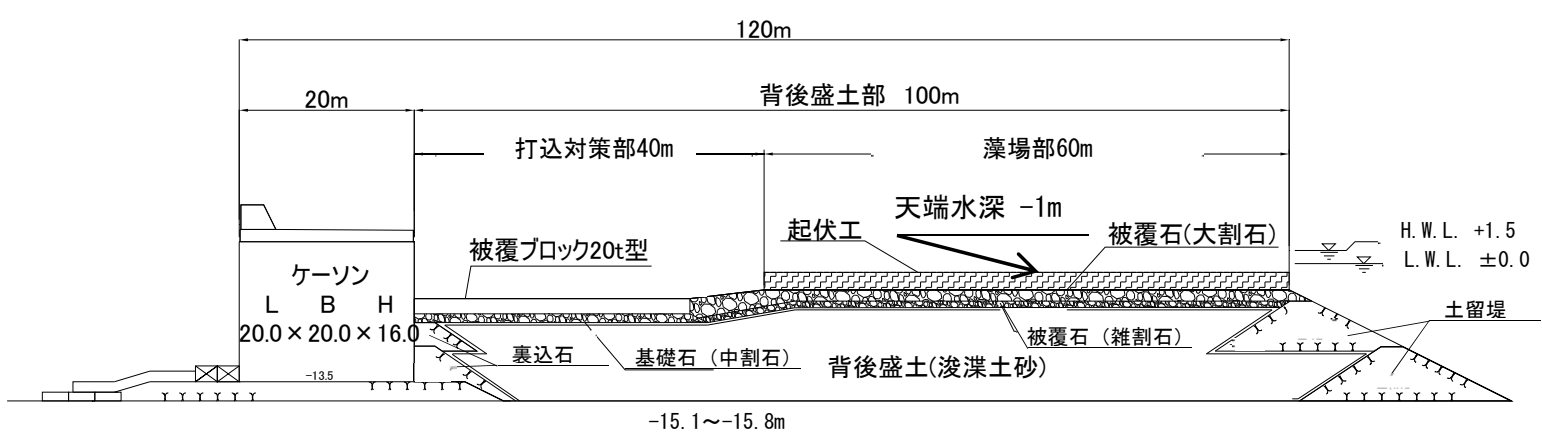

図-2 釧路港島防波堤の標準断面図 


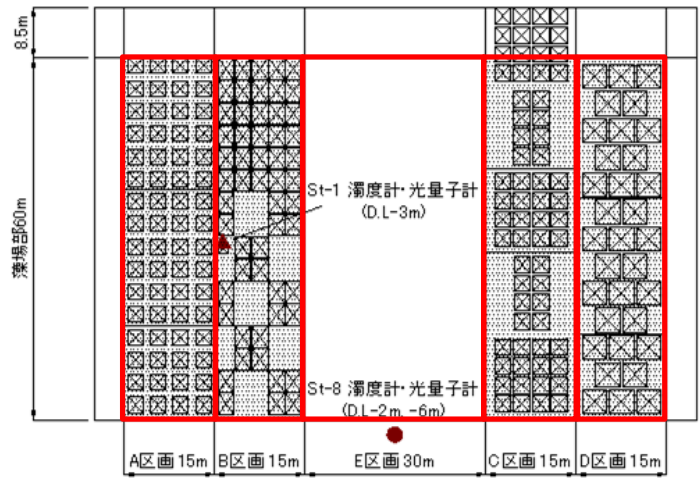

図-4 起伏工調査箇所

測線長 $100 \mathrm{~m}$ にたりダイバーの目視観察によって, 緑藻，褐藻，紅藻ごとの葉体被度を把握した。また， 夏期においては海藻の着生量を把握するため, 代表 地点において調查枠 $(0.5 \mathrm{~m} \times 0.5 \mathrm{~m})$ を設定して付着 生物（植物，動物）を採取し，種の同定，個体数, 湿重量の生物分析を行った。他に葉上葉間生物調査 も実施している.

物理量は光量子量観測, 濁度観測を実施してい る. 各調査とも (株) JFE アドバンテック社製のメモ リー式観測機器（ALW-CMP，ACLW-CMP）を用いて 15 昼夜から 30 昼夜ほどの連続観測を実施してデータ を取得した。

\section{4. 結果と考察}

\section{(1) 海藻の繁茂状況}

\section{a) 海藻出現種の変遷}

背後盛土完成後, 最初の海藻繁茂期となる2006年 7月には，既に褐藻綱であるナガコンブ Laminaria longissima Miyabe), ガッカラコンブ(Laminaria coriacea Miyabe)などのコンブ属や緑藻綱のアナア オサ, 紅藻綱のフイリタサ, カレキグサなどの出現 が確認された。その後，2007年（2年目），2008（3 年目）と経過するごとに海藻の出現種は増加してい る。ここで，図-5は2006年から2010年までの海藻繁 茂期における, 背後盛土上で確認された海藻の出現 種類数の割合を示したものである. 種類数の出現割 合から見ると初年度の 2006 年は, 紅藻綱が先行して

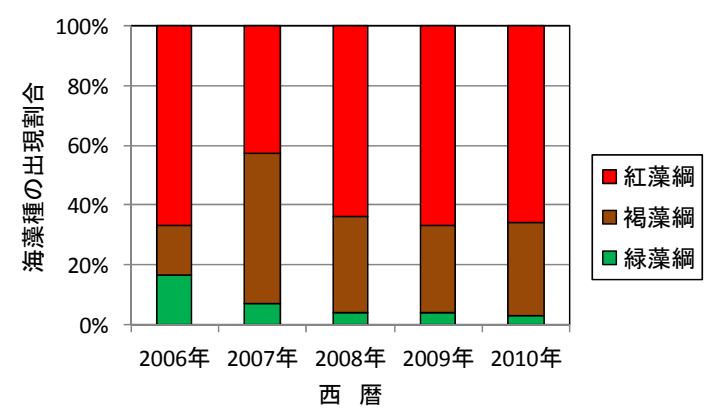

図-5 海藻出現種類数
出現しているが，2年目になると，コンブ類が属す る褐藻綱が出現し始めてきたことがわかる．3年目 以降は種類数から見れば一定の出現数となり, ほぼ 紅藻綱 : 褐藻綱 : 緑藻綱 $=20: 10 ： 1 の$ 割合となる. このように，施工当初から 3 年目くらいまでは，単 年生の紅藻綱や多年生の褐藻綱（コンブ類）の占有 に競合が見られる。その後は，海藻の種類数は増加 し藻場の多様性が図られるが，海藻種類の構成は一 定となっているもの考えられる.

\section{b) 海藻現存量}

2006 年度から 2010 年までの各年度におけるコン ブ類の区画内現存量の経年変化を図-6に示す。区 画とは，図-4に示した起伏工別に赤枠で囲った 5 区画のことを指す。なお，各区画には起伏工とし て写真-1 に示寸ような 4 種類のコンクリートブ ロック（A 区画に A ブロック等）を配置している. また，天端水深は，起伏工 A〜D 区画で D. L-1. Om, 起伏工を配置しない E 区画で D. L-3. 0m である.

起伏工における現存量は，2007 年（2 年目）が 最も多く，以降は増減を繰り返しながら藻場が維 持されている。しかしながら，起伏工がない E 区 画は，4 年目以降はほとんどコンブ類が生育してい ない状況にある。

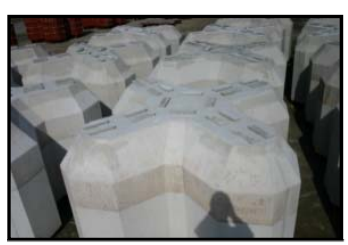

Aブロック

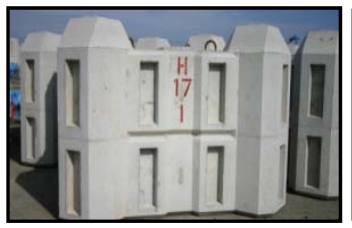

Cブロック

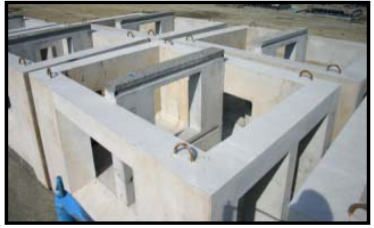

B ブロック

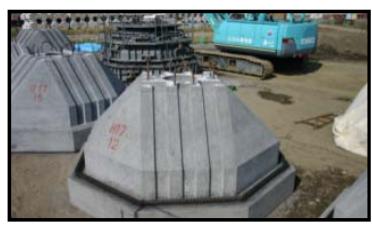

Dブロック
写真-1 起伏工用コンクリートブロック

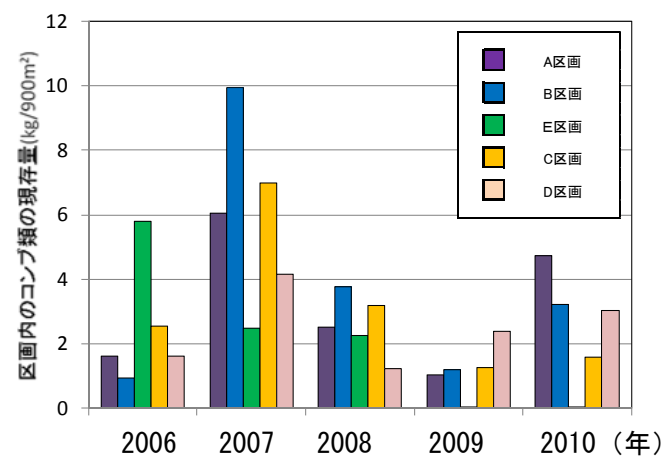

図-6 区画内のコンブ類の現存量 (海藻繁茂期7月) 

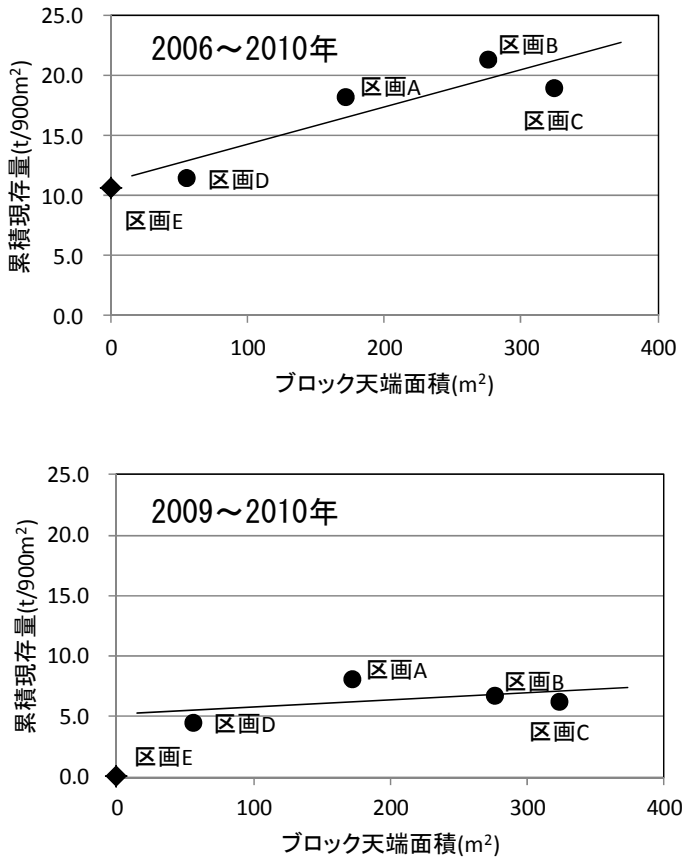

図-7 ブロック天端上のコンブ類現存量

起伏工用コンクリートブロックにおけるコンブ類 の着生部位は, ほとんど天端上のみであることが目 視観察で判明している. そこで, ブロックの天端面 積に対するコンブ類の現存量を図-7a 並びに図-7b に示す．なお，図の横軸は各ブロックの 1 個当たり の天端面積に設置個数をかけた起伏工天端総面積を とり, 縦軸は区画内のコンブ類現存量の 5 力年の累

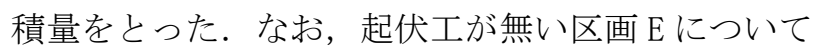
は便宜上，ブロック天端面積を $0 \mathrm{~m}^{2}$ とした。 図より まず, 天端面積が大きいブロックの方が海藻の着生 には有利に働くことが示唆される. 写真-1 に示した D ブロック（区画 D） は台形状をしており，逆に天 端面積が他のブロックに比べて小さいことから, 海 藻着生が少ない環境にあるものと推察される。

また，5力年全体（図-7a）においては各区画に相 関が見られるが，直近の 2 力年（図-7b）だけを見 ると, 起伏工が無い区画 $\mathrm{E}$ の現存量が大幅に減少し ている。そこで, 統計解析におけるノンパラメト リック手法の一つである Kruskal-Wallis（クラスカ ル・ウォリス） ${ }^{5}$ による各区画の関連性を調べた結 果を表-2 に示す。初期段階（2006〜2008 年）では,

表-2 Kruska1-Wallis検定結果

\begin{tabular}{|c|c|c|c|c|}
\hline \multirow[b]{2}{*}{ 対象年 } & 統計量 & $x^{2}$ & & \multirow[b]{2}{*}{ 判定 } \\
\hline & $K W$ & $\begin{array}{c}\text { 有意水準 } \\
(0.05)\end{array}$ & & \\
\hline 2006 2010年 & 7.76 & $<9.49$ & $p>0.05$ & 有意な差は無い \\
\hline 2006～2008年 & 9.11 & $<9.49$ & $p>0.05$ & 有意な差は無い \\
\hline 2009 2010年 & 13.87 & $>9.49$ & $p<0.05$ & 有意な差がある \\
\hline
\end{tabular}

有意な差は認められなかったが，その後の 2 力年を 対象とすると，区画 $\mathrm{E}$ の現存量の減少により，有意 な差があると判定された。

代表種であるナガコンブの寿命は約 3 年である. 整備直後には区画 $\mathrm{E}$ （割石部）でもナガコンブの着 生があり生長を続けていた。しかし，水深が起伏工 より深い割石部は, 窪地形状となっているため浮泥 が堆積しやすい環境にある。これが，海藻着生を阻 害する要因となり，ナガコンブの新規加入群が抑え られ世代交代が無かったことにより，初期段階を過 ぎた 4 年目において海藻が消失したものと推察され

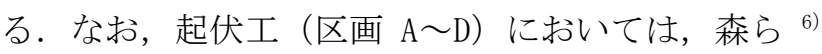
によると堆積した浮泥は波浪により十分に払拭され， コンブの着生に与える影響は小さいと報告している. よって, 起伏工は年変動こそあるが海藻の生態サイ クルがなされた中で藻場が形成され，その藻場を持 続させるためには, 新規加入群による世代交代が可 能となる環境条件が必要になると考えられる.

\section{（2）起伏エにおける濁度と光量子量}

当該砂浜海域において, 海藻の生態サイクルに 影響を与え藻場の持続性を阻害する濁度上昇（光量 子量低下）について検討した，検討には，波浪が最 も高くなる秋期（2010年10月～11月） と海藻生長期 である春期（2011年2月）における海域の濁度およ び光量子量の観測結果を用いた，なお，濁度と光量 子の観測地点と水深は図-8に示すとおりである.

観測結果として時系列を図-9に示す。縦軸の日 平均濁度は，全地点の 10 分間隔で測定した 1 日にお ける濁度の平均值である。同じく日積算光量子量は, 10 分間隔で測定した 1 日分の光量子量を積算した值 である。なお，ナガコンブの生育に必要な最低光量 子量である日補償光量 $0.52 \mathrm{~mol} / \mathrm{m}^{2} /$ dayを図中に示し た7)。全体としては，秋期においては，ナガコンブ の生育に十分な日補償光量を確保している. 同じく, ナガコンブの生長にあたり最も光量が必要と考えら れる春期（2011年2月）において, 起伏工の天端水 深（水深-1m）の妥当性を検証するために，異なる 水深帯における濁度と光量子量を観測した．その結 果を図-10に示す．なお，水深- $2 m ，-3 m$ は起伏工付 近，水深-6mは土留堤法面部であり，この水深帯は 島防波堤におけるこれまでの目視観測で確認されて いるナガコンブの着生の限界水深とされる付近であ る. 図より, 起伏工近辺のSt. 1 (-3m) およびSt. 8(2m) は，天候の違いによって日積算光量子量が変動 しており, その数值はナガコンブの生育に必要な日 補償光量を十分満足している. 水深が深くなる St. 8 (-6m) は, 前述のナガコンブの日補償光量と同 程度であり，この水深帯 $(-6 \sim 7 \mathrm{~m})$ がナガコンブの 


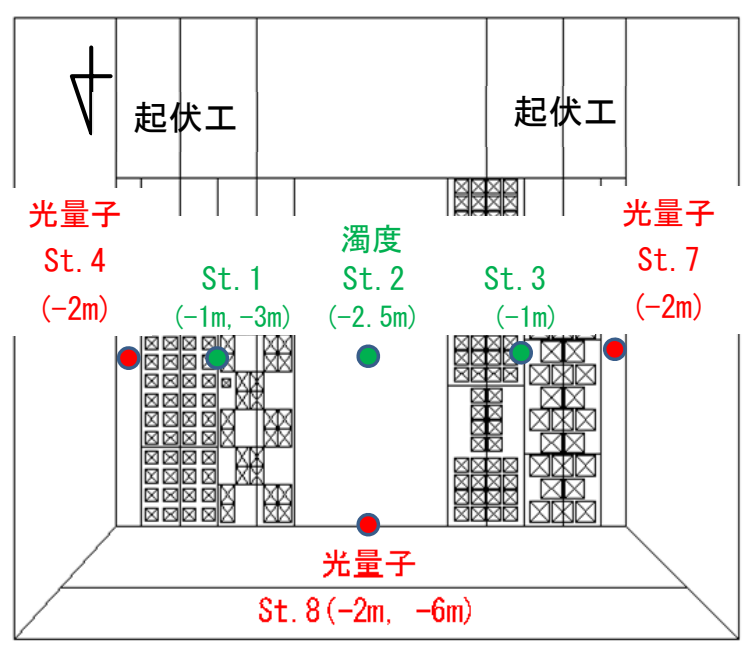

図-8 濁度と光量子量の観測地点

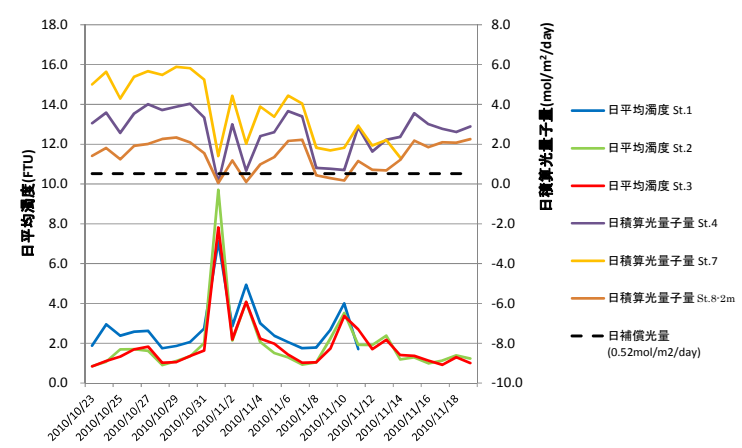

図-9 濁度と光量子量の時系列（2010年秋期）

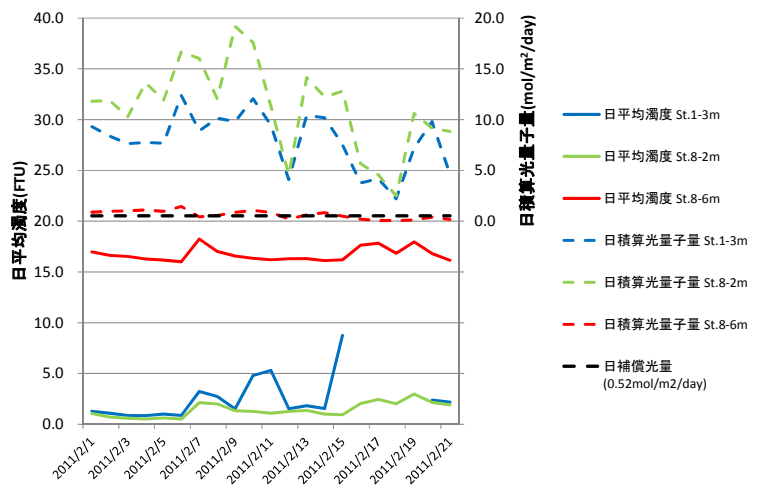

図-10 濁度と光量子量の時系列（2011年春期）

生育限界であることが改めて確認された。 よって, 天端水深を上げて海藻の生育環境の向上を図った背 後盛土構造の効果が確認された。

また，2011年2月の背後盛土上の日平均濁度およ び日積算光量子量の関係を図-11に示す。この図よ り起伏工周辺である水深 $2 \mathrm{~m}$ 以浅の濁度は5FTU以下で あり，過年度の調查結果 ${ }^{3)}$ によるナガコンブの生育 基準（濁度8以下）を満足している.

以上により，起伏工設置による天端の嵩上げは，

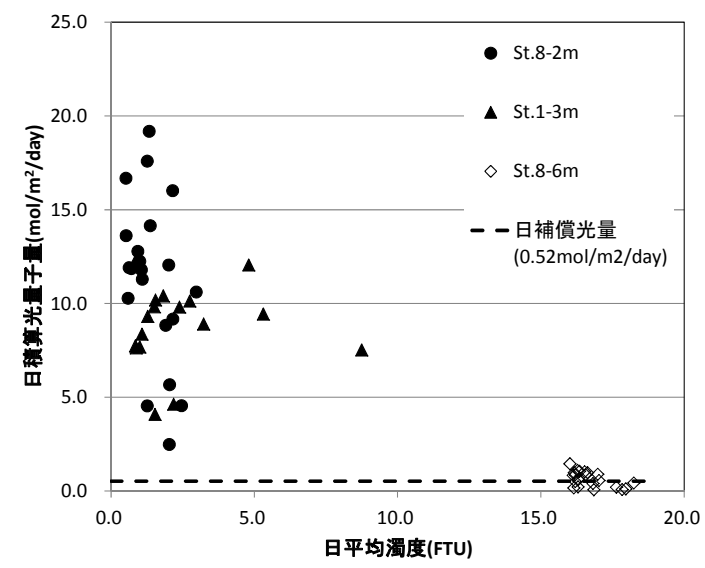

図-11 濁度と光量子量の関係（2011年春期）

コンブ類の生育環境を向上させ新規加入群による世 代交代を促し，藻場の持続性に寄与寸るものと考え られる。

\section{（3）生物生息分布}

背後盛土上に生息する魚類, ウニ，カ二類の出 現種と生息分布を把握することを目的に，生物追跡 調査を行った，各区画において，幅約 $5 \mathrm{~m}$ の範囲で 南北方向に 1 往復半 (約 $60 \mathrm{~m} \times 3)$ の距離を目視観 察することで，区画全体（約 $60 \mathrm{~m} \times 15 \mathrm{~m} ）$ に生息す る生物の出現箇所を把握した。確認された生物の生 息分布を図-12 に示寸. 魚類 3 種, ウ二類 1 種, カ 二類 2 種の出現が確認された（写真-2）。個体数は, 魚類が各区画で $1 \sim 2$ 個体，ウ二類が 10 個体以下/ 区画，カ二類が 5 個体/区画であった。魚類は特に B 区画に多い傾向にある。これは B 区画のブロック
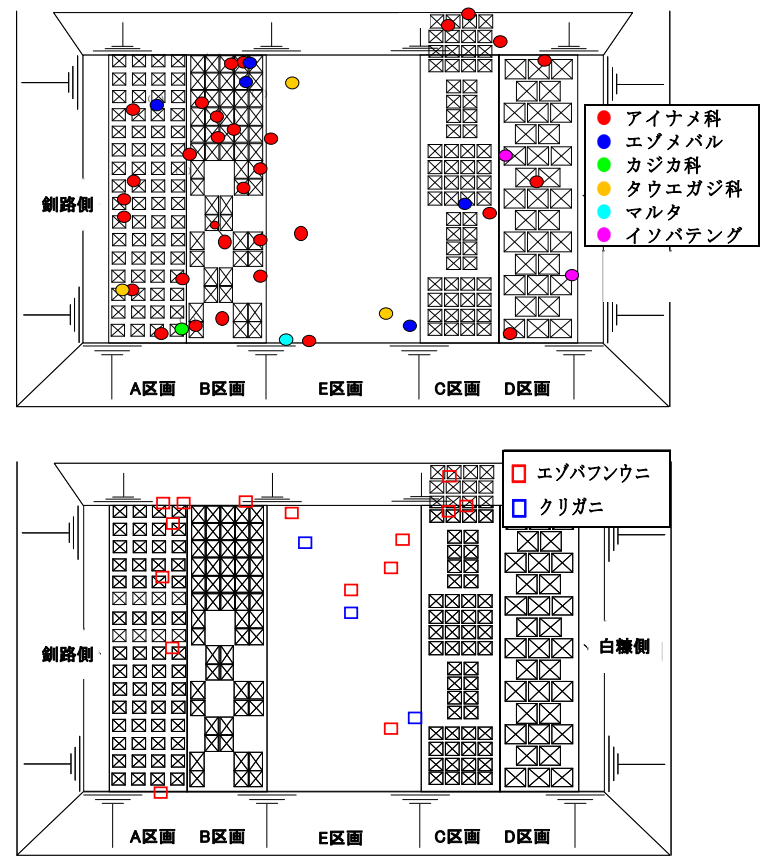

図-12 生物生息分布図 (2009.7) 

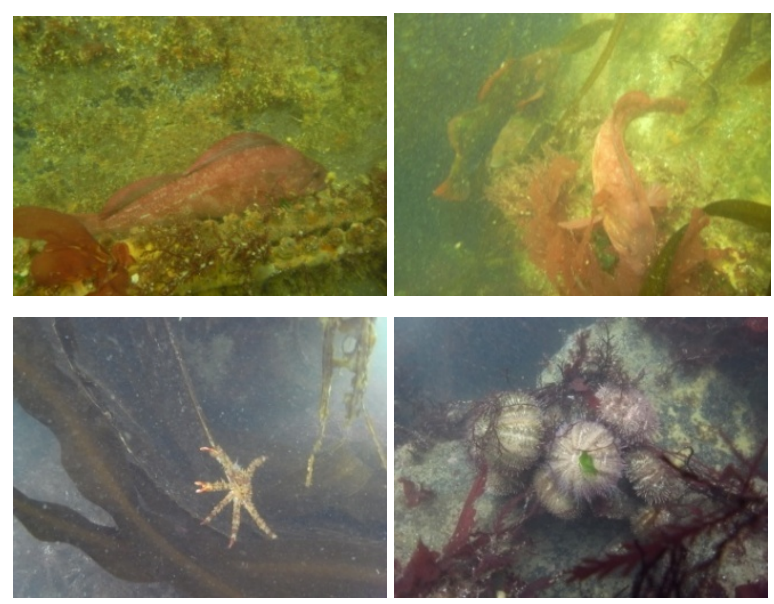

写真-2 確認された魚介類の一例

が中空形状であるため, 魚礁としての効果が発現し ているものと推察される。底棲動物であるエゾバフ ンウニやクリガニは通路部や起伏工の区画でもブ ロックでは無く下部の割石に生息していることが確 認された。これは, 浅い水深帯での速い流れを嫌っ て水深の深い通路部やブロックの陰に生息する傾向 があるものと推察される，以上のように，整備後 4 年が経過した時点においても，岩礁域に生息する魚 類が多数蝟集しており, 藻場の維持が多様な生物生 息場環境を継続させているものと考えられる。

\section{5. まとめ}

砂浜域に新たに創出された疑似岩礁としての起 伏工においては,

(1)岩礁性の海藻群落が持続的に形成され，十分に藻 場創出機能を有している.

(2)起伏工用のコンクリートブロックにおける海藻 着生は天端部のみに限られ, 天端面積の大きい形状
を持つブロックが有利に働く傾向にある.

(3)起伏工天端が浅いため, 濁りのある砂浜海域に おいても，海藻の生育に必要な光環境が良好である. (4)藻場の形成に伴い魚類が蝟集し, 産卵場, 保育 場, 餌場などの多様な機能の持続性が確認された.

しかしながら, 将来にわたって藻場環境を維持 していくためには, 長期的な気候変動や河川等陸域 からの影響などが重要な課題となってくる.今後は, これらの影響を考慮しながら藻場造成効果の持続性 について検討していく予定である.

\section{参考文献}

1）海の自然再生ワーキンググループ著 : 海の自然再生 ハンドブック藻場編, pp. 10, （株）ぎょうせい, 2003.

2）北原繁志・繁本 護・根本任宏・丸山修治 : 釧路港 島防波堤背後盛土上の物理環境と藻場形成に関する 研究, 寒地土木研究所月報, No. 657, pp. 24-32, 2008.

3）佐藤 仁・福田光男 - 丸山修治・村井克詞：防波堤 に形成された背後盛土における藻場機能について, 海洋開発論文集, Vol.25, pp. 329-334, 2009.

4） (社）寒地港湾技術研究センター編：寒冷地におけ る自然環境調和型沿岸構造物の設計マニュアル -藻 場・産卵礁機能編-, pp. 13, 1998.

5）岩崎 学: 統計的データ解析入門 ノンパラメトリッ ク法, (株) 東京図書, 2006 .

6）森 信幸・橋詰知喜・丸山修治・坪田幸雄 : 釧路港 藻場創出機能付き防波堤の堆積砂制御について, 平 成 14 年度日本水産工学会学術講演会講演論文集, pp. 141-144, 2002.

7）坂西芳彦・鈴木健吾・宇田川徹・飯泉 仁・山本正 昭 : 釧路沿岸における夏期のナガコンブの日補償深 度, 北海道区水産研究所研究報告, 65 号, pp. 45-54, 2001.

\section{SUSTAINABLE FACTOR OF SEAWEED BED AT COASTAL STRUCTURE IN SAND COAST}

\section{Jin SATO, Jun YAMAMOTO, Hiroaki YAMAUCHI, Hiroshi IMABAYASHI and Toshihiko YAMASHITA}

In the Kushiro port of Hokkaido, the rear step of shallow depth was made by using the dredged sand on the offshore breakwater. The purpose to set up the rear step is a creation of the seaweed bed in addition to the decrease of the transmission wave by the wave-overtopping and the cost reduction by the reinforcement of the main caisson.

This study is about the seaweed that grows thickly on the rear step and the environment of light on the rear step. The results are as follows: A large seaweed bed with mainly kelp is formed. It has been understood that the seaweed grows only to the upper part of concrete blocks. In this place, the amount of the photon is enough for photosynthesis of the kelp. The seaweed bed has changed from mainly diatom to mainly kelp. The species swarming in the marine forest increase every year. 